\title{
BIBLIOGRAPHY
}

ALBRIGHT, F., SMITH, P. H., and FRASER, R. (1942), צ. Clin.

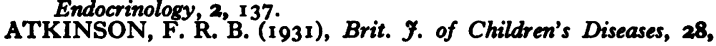
I2I.

BAUER, W., and AUB, J. C. (194I), 7. Clin. Invest., 20, 295.

CHUTE, A. L., ROBINSON, G. C., and DONÖHUE,' W. L.

COGGES), Y. Paediatrics, 34, I. 26, 1 .

CROOKE, A. C., and CALLOW, R. K. (1939), Quart. F. Med.,

CUSHING, H. (1912), 'The Pituitary Body and its Disorders,' J. B. Lippincott \& Co., Philadelphia.

CUSHING, H., and DAVIDOFF, L. M. (1927), ' Rockefeller Institute for Medical Research Monographs,' New York.

DAVIDOFF, L. M. (1926), Endocrinology, 10, 461.

DAVIS, A. C. (1940), "Transactions of Amer. Assoc. for Study of Goitre.

ELLINGER, P., HARE, D. C., and SIMPSON, S. L. (1937), Quart. F. Med., 6, 24I.

ELLIIS, F. (1949), Proc. Roy. Soc. Med., 42, 853.

FORBES, J. E., GUSTINA, F. G., and POSTOLOFF, A. V. (1943), Amer. F. Dis. Child., 45, 593.
GOLDBERG, M. B., and LISSER, H. (1942), צ. Clin. EndoHURXTHAgl, 2, 477. M., HARE, H. F. E., HORRASE, G., and POPPEN, J. L. (1949), Ұ. Clin. Endocrinology, 9, 126. JOSEPHSON, B. (1936), Acta. Med. Scand., $90,385$.

KINSELL, L. W., MICHAELS, G. D., LI, C. H., and LARSEN, W. E. (1948), 7 . Clin. Endocrinology, 8, 1013.

LI C. H. (1950), Lancet, $1,213$.

MÁINZER, F., and YẢLAỨSis, E. (1937), Folia Clin. Orient., I, 37.

MCNEE, J. W. (1950), Brit. Med. F., I, 113.

NORTHFIELD D. W. C. (I949), Proc. Roy. Soc. Med., 42, 845 OPPENHEIMER, B. S., and FISHBERG, A. M. (1924), Arch. Int. Med., 34, 631 .

SCHRIRE, J., and SHARPEY-SCHAFER, E. P. (1938), Clinical

Science, 3, 413.
SCHRIRE, J. (1948), F. Endocrinology (Gt. Britain), 5, 274;

SIMPSON, S. L. (I048), 'Major Endocrine Disorders,' Oxford University Press, London.

TURNER, H. H. (I938), Endocrinology, 23, 566.

WALTERS, W., WILDER, M., and KEPLER, E. J. (1934), Annals of Surgery Oct. p. 670 .

YOUNG, F. G. (1937), Lancet, 2, 372.

\section{DIABETES INSIPIDUS}

\author{
By A. A. G. Lewis, B.Sc., M.D., M.R.C.P. \\ Saltwell Research Fellow, the Royal College of Physicians \\ From the Medical Professorial Unit, The Middlesex Hospital
}

Thomas Willis, in 1682 , distinguished between saccharine and non-saccharine diabetes. Frank (in 1794) defined diabetes insipidus as a long-continued, abnormally-increased secretion of non-saccharine urine, not caused by renal disease. It is now known to be due to a failure of water reabsorption by the renal tubules as the result of an ineffective level of circulating anti-diuretic hormone (ADH). Cases where the renal tubules can be shown to be insensitive to the action of the hormone occur extremely rarely (Williams, 1946).

\section{Clinical Picture}

Diabetes insipidus may occur at any age, but is more common in the young. In Jones' series of 42 cases (1944), 17 occurred in the first ten years of life. Males are more often affected than females.

The onset is usually insidious, the patient noticing a tendency to thirst and dryness of the mouth, with polyuria and nocturia. There may be some loss of appetite, and the dryness of the mouth may make mastication difficult and food less appetizing. Loss of weight may occur, though some cases gain. Loss of appetite and exhaustion from loss of sleep may lead to emaciation in severe cases. Occasionally the appetite is increased.

In a few cases the onset is sudden and dramatic with intense, unquenchable thirst and polyuria. These patients may remember for years exactly when and where their illness began and may say that the thirst occurred after some particular food had been eaten. Sometimes a shock or an accident may be blamed.

In severe cases the thirst is extreme, the patient developing a dry mouth if he abstains from fluid for more than an hour or so. Very often the thirst seems to be abnormal in quality as well. It may be described in dramatic terms, the patient emphasizing the 'burning sensation' in the mouth and throat. Sipping water is only a temporary palliative however; the patient often feels compelled to drink a large quantity of waterhe feels he must 'drain the glass to the dregs' or ' get it right down inside.' Water is often preferred to all other fluids and some patients become connoisseurs of water, preferring that from one source to that from another in flavour. Many find iced water more satisfying.

Deprived of water, the sufferer may go to any lengths to get fluid, drinking from flower vases, puddles or fountains, or filling his mouth with snow, or even drinking his own urine. It is not surprising that some of these patients, constantly tortured by thirst, unable to follow any normal occupation on account of the polyuria and prevented from sleeping for more than an hour or so at a time, should develop neurotic symptoms. Headaches, apathy, weakness, inability to concentrate, irritability and insomnia may be com- 
plained of, though in some cases these symptoms are probably associated with loss of salt.

In severe cases the urine volume may exceed ro litres a day and much higher figures have been recorded. Trousseau's famous case passed 43 litres in 24 hours. While it is probably true that the more severe cases tend to have a more constant output of urine, variations do occur from time to time. The day volume is greater than the night and may be increased by anxiety. or reduced in an intercurrent infection. Since the renal tubules cannot concentrate the urine in the absence of $\mathrm{ADH}$, any call for the increased excretion of osmotically active substances (especially salt and urea) will increase the volume of urine (Beaser, 1947).

The specific gravity of the urine is always low, usually below roo5. The significance of the variations in urine volume and specific gravity which occur with fluid restriction will be discussed later.

Diabetes insipidus is a symptom complex and the underlying cause must be carefully sought. Hyperparathyroidism should be remembered as an occasional cause of polyuria.

\section{The Anti-Diuretic Hormone}

This is formed by the neurohypophysis. It is generally believed to be identical with vasopressin, and it is doubtful whether this has any other action normally in the body, though Heller (1940) has reported separating the anti-diuretic from the pressor effect. Pitressin is the proprietary name given to a preparation of vasopressin which is said to be practically free of the oxytocic factor.

The hormone can be adsorbed and inactivated by blood and tissue extracts. It is probably removed from the blood stream partly by destruction in the liver and, to a lesser extent, by excretion in the urine, in which it can be assayed by suitable techniques (Burn, I931; Heller and Urban, I935; Grollman and Woods, I949). In cirrhosis of the liver it has been suggested that slow destruction of the hormone may be partly responsible for water retention (Ralli, et al., 1945).

\section{The Neurohypophysis}

The terminology introduced by Rioch, Wislocki and O'Leary (1940) for the more accurate description of the pituitary gland is now being generally adopted. The gland is divided into adenohypophysis and neurohypophysis, the latter consisting of the median eminence of the tuber cinereum, the infundibular stem and the infundibular process, which together form, histologically and functionally, a single unit (see fig.). A dense bundle of unmyelinated fibres (the supra-

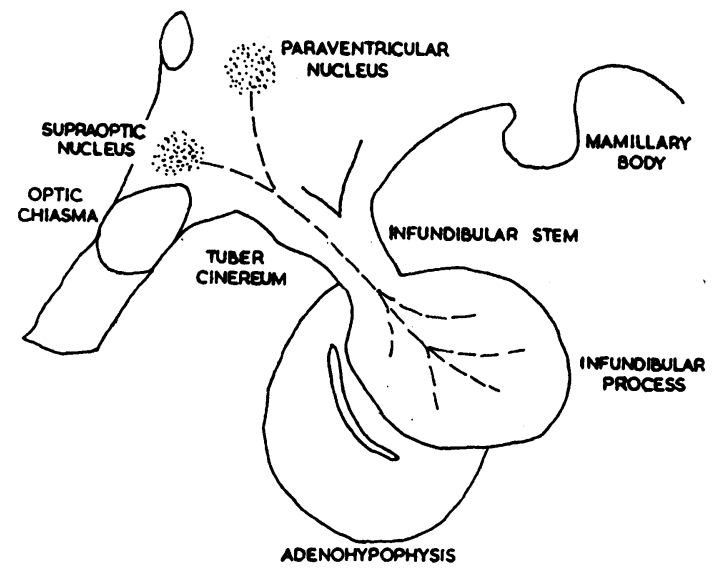

Diagrammatic representation of the course of the supraoptico-hypophysial tracts in man.

(Drawn bv Professor E. W. Walls.)

optico-hypophysial tract) passes from the supraoptic nucleus in the hypothalamus, with some fibres from the paraventricular nucleus, to the neurohypophysis. The mode of termination of these fibres is uncertain. It is thought that the pituicytes, large glial cells found throughout the neurohypophysis, may actually elaborate the hor mone. They degenerate after section of the supraoptico-hypophysial tracts, and retrograde degeneration occurs in the two hypothalamic nuclei.

\section{The von Hann Theory (rgr8)}

In spite of the fact that posterior pituitary extracts were shown to control the polyuria of diabetes insipidus in 1913, the role of the hypothalamus and of the anterior lobe remained in dispute for many years. In 1918 von Hann first reconciled the conflicting results of animal experiments, suggesting that some continued function of the anterior lobe, in the absence of the secretion of the posterior lobe, was necessary for the maintenance of the polyuria. Complete hypophysectomy does not lead to diabetes insipidus, nor, clinically, does Simmond's disease, in which the water exchange is reduced. Exactly how the anterior lobe is responsible for this is not known. It may produce an actively diuretic principle, but it seems more likely that it is the maintenance of normal metabolism and activity, by the thyroid and the adrenals, that is essential. Thus thyroidectomy greatly reduces the severity of the polyuria in diabetes insipidus, and there is a failure of the normal response to the ingestion of water in adrenal insufficiency. This has been further investigated in dogs by Pickford and Ritchie (1945). 


\section{The Hypothalamus}

The confusion as to the role of the hypothalamus in the causation of diabetes insipidus was finally ended by the work of Fisher, Ingram and Ranson (1938) who conclusively proved that bilateral interruption of the supraoptico-hypophysial tracts produces the disease in the cat and monkey. No other lesion has consistently been shown to do this. Nearly complete destruction of the gland or tracts is necessary to produce diabetes insipidus; in the cat subtotal lesions produce less severe degrees of the disease. This appears to be true in man also. A temporary phase of polyuria and a brief normal interval occur before the polyuria becomes permanently established.

\section{The Normal Processes of Urine Formation}

The nephrons elaborate urine by a process of glomerular filtration, followed by the reabsorption of the greater part of this filtrate by the tubules. In a normal man about $I, 000$ to $1,400 \mathrm{cc}$. of blood flow through the kidneys per minute, the glomeruli filtering off $130 \mathrm{cc}$. of plasma water with its dissolved crystalloids. Of this, more than Ioo cc. are always reabsorbed, probably in the proximal half of the tubule (Smith, 1947). It is believed that the final concentration of the urine takes place in the distal tubule (probably mainly in the thin segment of Henle's loop) where varying quantities of water are reabsorbed under the control of $\mathrm{ADH}$ released into the blood stream by the neurohypophysis.

Under ordinary conditions the glomerular filtration rate (measured by the inulin or sodium thiosulphate clearances) remains remarkably constant and variations in the rate of urine flow are thought to be effected by varying blood levels of $\mathrm{ADH}$, to which the renal tubules are extremely sensitive. Secretion of urine ceases if the glomerular filtration rate falls to very low levels (as with very low arterial pressures) and at very high rates of urine flow the filtration rate rises, possibly from dilution of the plasma proteins by the large water load ingested. Between these extremes, however, there is no evidence that variations in renal blood flow or glomerular filtration rate affect the urine flow. It is possible that $\mathrm{ADH}$, by acting on the glomerular arterioles, may produce small changes in the filtration rate but these probably play no part in its essential action.

The greater the tubular reabsorption of water the more concentrated does the urine become. Its specific gravity and osmotic pressure rise, though not all the constituents are equally affected. More urea is reabsorbed for instance (this is probably a process of passive back-diffusion) so that less urea is removed from the blood per minute at low rates of urine flow (that is, the urea clearance falls). On the other hand, the concentration of chloride in the urine rises until it reaches a maximum of about $1,200 \mathrm{mg}$. per cent. (as $\mathrm{Cl}$ ), which implies that for every cc. of water reabsorbed less chloride passes back. This appears to be the specific effect of the hormone but it is often said that it increases the output of chloride by the human kidney. This question has recently been further investigated and it has been shown that in normal men the hormone increases the concentration of chloride in the urine leaving the minute output unchanged, or reducing it slightly (Chalmers, Lewis and Pawan, 1950). There is in fact no evidence that $\mathrm{ADH}$ has any other action in normal men than to stimulate the renal tubule to reabsorb more water. The factor that limits the tubular reabsorption of water, and therefore determines the minimum urine flow that can occur under the action of $\mathrm{ADH}$, appears to be the total osmotic pressure exerted by the urine solutes.

Suggestions that the posterior pituitary hormones might have other actions, e.g. on a hypothetical water regulating centre in the midbrain or hypothalamus, on the hydration of the tissues or on the osmotic pressure of the plasma proteins are not supported by the evidence.

Renal function has been investigated in diabetes insipidus by Winer (1942) who found the filtration rate to be normal before and after treatment with pituitrin, though there was a sharp, temporary de crease just after the injection.

Factors Influencing the Production of ADH (Pickford, 1945; O’Connor, 1947)

Claude Bernard showed that emotion could inhibit the flow of urine. Emotional changes seem to be responsible for the release of $\mathrm{ADH}$ brought about by exercise (Rydin and Verney, 1938) and by pain (Kelsall, r949). Various sensory stimuli will inhibit a water diuresis in animals, and the stimulus can be so conditioned that the inhibition can be produced by the mere preparation of the animal for the experiment, or even by a musical note. In man, a water diuresis can be initiated by suggestion under hypnosis (Marx, 1926).

Pickford (1947) has shown that acetylcholine will cause the release of ADH in the dog when injected into the supraoptic nucleus, and Burn, Truelove and Burn (1945) showed that in man intravenous injections of nicotine, or smoking cigarettes, will do so (Walker, 1949). Estimations of the inulin clearance in this laboratory have shown that this is due to increased tubular reabsorption of water.

Dehydration appears to be the 'normal' stimulus increasing the output of hormone. It has frequently been shown that the urine of dehydrated animals contains an anti-diuretic sub- 
stance. This disappears after destruction of the supraoptico-hypophysial tracts. (These results should not all be accepted without reserve. Other anti-diuretic substances might be present in urine, and the methods of assay have not always been above criticism. As an example, the urine of smokers contains nicotine, which will inhibit a water diuresis when injected into rats unless care is taken to remove it.)

It is this stimulus that has been so fully investigated by Verney and his co-workers at Cambridge (Verney, 1946). They have shown in dogs that it is the osmotic pressure exerted by some of the plasma crystalloids which controls the release of the hormone. Changes can be brought about, with subsequent inhibition of a water diuresis, by injections of hypertonic solutions into the common carotid artery, and the amount liberated can be estimated by comparing the duration of inhibition with that produced by injecting a known quantity of hormone. Changes in the osmotic pressure of the carotid blood of about 2 per cent. are effective. Verney believes that special 'osmoreceptors' are responsible for controlling the output of $\mathrm{ADH}$ from moment to moment, and has very tentatively suggested that the small vesicles which can be seen in sections through the supraoptic nucleus may be the receptors themselves. According to Verney, a water diuresis only occurs when, following the ingestion of water, dilution of the blood leads to the cessation of the activity of the osmoreceptors (" physiological diabetes insipidus '). There is a time lag of some ${ }_{5}$ minutes after the peak of the water load before the maximum rate of urine flow is attained, presumably because this is the time taken for the circulating hormone to be removed or inactivated.

\section{Thirst in Diabetes Insipidus}

There is no doubt that this experimental work offers a very convincing explanation of the nature of the clinical condition, and there might seem to be little room for further argument. It deals, however, solely with the factors controlling water output and only indirectly with that sensation which must ultimately regulate the organism's water exchange, namely, thirst. If water loss did not rapidly lead to thirst and the ingestion of water, death would soon follow, while diabetes insipidus, as defined above, would certainly be the result if some prolonged and abnormal increase in thirst were to occur.

The problem of thirst has been discussed by Gregersen (194r). The older view is that it is a sensation arising centrally, from changes in the hydration of the tissues. Cannon suggested that it is purely local in origin, arising from dryness of the mouth and throat. If this were true, extirpation of the salivary glands should lead to increased drinking, but Montgomery (I93I) found that this did not follow in dogs. Gregersen and Cannon (1932) repeated this work, drying the buccal mucosa as well by exposing it to warm air, but even then the dogs only drank twice as much as before. Cannon found that atropine made him thirsty when it made his mouth dry: most people who have tried this would probably say that the dryness leads to a desire to wet the mouth, not to drink large quantities of water. Nervous women with xerostomia, or patients with ureo-parotid tuberculosis or with Sjögren's syndrome (Ellman and Parkes Weber, I949) do not develop diabetes insipidus, though they may drink more often than other people.

Gilman (1937) has suggested that thirst is the result of the loss of intracellular fluid, which is the older view in modern terminology, and this does not seem inconsistent with the known facts. It would explain why thirst should occur after haemorrhage, which reduces the extracellular fluid volume, and after infusions of hypertonic saline, which increase it. It seems probable that thirst arises from intracellular dehydration, while extracellular fluid loss, by reducing the blood flow through the salivary glands (Gregersen), reduces the salivary flow. Usually, of course, the two occur together.

Holmes and Gregersen (1948) investigated the origin of the thirst in diabetes insipidus by studying the weight, thirst, salivary flow, plasma volume, 'thiocyanate available fluid' and plasma proteins and sodium in five cases under three sets of conditions: (I) when fluids were allowed ad lib. (2) when pitressin was given to control the polyuria, and (3) when fluids were forced until thirst disappeared and the salivary flow approached that observed in period (2). In the last two periods, compared with the first, changes were consistently observed identical with those found in dehydrated men after the ingestion of waterthe weight, salivary flow, plasma volume and 'thiocyanate space' rose, while the plasma proteins and sodium fell. They believed that Cannon's theory of thirst could be applied to diabetes insipidus, the dehydration leading to a dry mouth and so to thirst. These results do noi rule out the possibility of over-hydration in periods (2) and (3), as no figures for normal estimations are given. They believed this was excluded since pitressin and forced fluids will not increase the salivary flow in normally hydrated men. Theobald (1934), however, found that if a water diuresis in a hydrated dog were inhibited by pituitrin, excessive salivation did occur. That pitressin can lead to chronic over-hydration is 
shown by the results of fluid restriction in a case reported recently at the Royal Society of Medicine (Lewis, Ward and Bishop, 1949). Fluids were restricted on two occasions, once after daily doses of pitressin or pituitrin snuff and once four clear days after any treatment had been given. On the first occasion, in the course of the 12 hours that followed the end of the anti-diuresis produced by the last dose of pituitrin, nearly 5 litres of fluid were lost, yet the urine flow remained above $5 \mathrm{cc}$. per minute and the specific gravity was less than 1005. On the second occasion I9 hours' deprivation reduced the urine flow to less than I cc. per minute with a specific gravity of 1010.5, in spite of a total loss of less than 3 litres of fluid. The mouth was not really dry on either occasion, though thirst was great (see also Thorn and Stein, 1941).

\section{The Role of Polydipsia}

The view that thirst is the cause and not the result of diabetes insipidus, in spite of the impressive weight of evidence to the contrary, cannot be lightly dismissed. This was certainly the opinion of many of the older clinicians, who considered the disease as psychopathic in origin or referred to it as 'nervous polyuria.' Later, hysterical thirst was considered in France to be a separate condition and was termed 'potomanie.' Cushny (1926) and Cushing (1932) both suggested that the polydipsia was primary. Many patients are absolutely convinced that their thirst began before their polyuria, and there are several case reports in the literature (Nothnagel, I88I; Futcher, 1904; Kennaway and Mottram, 1919; Weir, Larson and Rowntree, I922; Kourilsky, I947). In Dandy's case (1940), the pituitary stalk was deliberately cut at operation: thirst appeared soon after the return of consciousness and was quickly followed by a very high output of urine. The water intake greatly exceeded the urine volume for ten days.

Other clinical evidence sometimes advanced to support the theory of primary polydipsia is perhaps less convincing. Patients will often maintain that injections of pituitrin relieve their thirst very rapidly, long before much effect on body hydration could have occurred, or declare that pituitrin promptly increases their salivation. Both these effects may be psychological, however; and even control water injections may not decide this, for patients can sometimes tell from bladder sensations when the injection ' begins to work.'

Experimental evidence in favour of the theory of polydipsia was given by Bailey and Bremer (I92I) who believed that polydipsia and polyuria occurred simultaneously and independently, by Curtis (1924) and by Swann (1939). These findings have been criticized by Fisher, Ingram and Ranson: (1938). Bellows and van Wagenen (1938) repeated an earlier experiment of Claude Bernard, making 3 oesophageal fistulas in dogs so that the water in-क take could be completely dissociated from the out- $c$. put, the dogs being given a measured quantity of $\overrightarrow{\vec{F}}$ fluid into the lower end of the oesophagus. Diabetes insipidus was then produced by bperation? on the hypothalamus or pituitary. In the tem- 흠. porary phase a marked polydipsia occurred, with $\frac{\bar{N}}{\sigma}$ polyuria only on the first day. In the permanent $\stackrel{\mathbb{Q}}{2}$ phase polydipsia was the sole abnormality, the dogs suffering no ill effects from losing, through $\overrightarrow{0}$ the fistula, all the excess water drunk. If they were given more water into the stomach, the $\vec{\omega}$ polydipsia was reduced but not abolished. The dogs could, however, pass a fairly concentrated 0 urine. Though there was no obvious evidence of 3 . dehydration, there may have been sufficient to $N$ stimulate both the thirst and the production of $\tilde{c}_{0}$ $\mathrm{ADH}$ from some residual tissue. The findings in + Dandy's case might be explained along similar $\underset{A}{N}$ lines, for there may have been a greatly increased extra-renal fluid loss following the operation.

The view that there might be two types of diabetes insipidus was put forward by Veil (1916). $\mathrm{He}$ believed that polydipsic and polyuric forms existed, but his final division was into hypor $\overrightarrow{0}$ chloraemic and hyperchloraemic types. In France, Veil's earlier view has been greatly extended Kourilsky (1947) who has studied the effects of prolonged fluid deprivation on 30 patients. He divided them into:-(I) Pure polydipsia: five cases. The urine is reduced in volume and $\frac{Q}{2}$ normally concentrated if the fluid deprivation is $\stackrel{2}{\vec{A}}$ prolonged. The symptoms and signs arise from $\frac{0}{3}$ excessive water ingestion (see below). Two $\frac{3}{\partial}$ showed a normal hypothalamo-hypophysial system 훙 at necropsy (Roussy, Kourilsky and Mosinger, 1946). (2) Pure polyuria: six cases. This corres- $\frac{3}{3}$ ponds in every respect to the disease produced in cats by Fisher, Ingram and Ranson. There is constant polyuria of low specific gravity, little $\delta$ affected by fluid restriction, the gravity remaining below roro even when a fluid deficit of 3 litres 0 has developed. Dehydration and haemoconcentration occur. (3) Mixed forms: I9 cases. 을. These may be due to partial lesions of the neurohypophysis. Here the urine volume and specific $N$ gravity can be influenced to some extent by the $N$ intake, but the thirst seems to be the dominant symptom and the effects of excessive fluid intake complicate the picture.

The effects of excessive water drinking have $\stackrel{0}{\mathbb{D}}$ been studied by Veil and by Kourilsky, the latter $\stackrel{\oplus}{\rightarrow}$ emphasizing that different changes in the blood chemistry occur in different subjects. Kunstmann, for example, in r 933 dra nk between 10 and 
18 litres a day for 127 days. After the first eight days there was an active desire for water and he had to drink during the night, even if he had done so before retiring. If water was not drunk, dryness of the mouth and difficulty in mastication occurred. His weight remained constant and the plasma chloride rose in spite of a negative chloride balance. At the end of the experiment he had great difficulty in reducing his water intake. It is, of course, well known that continuous drinking has a dehydrating effect (Wolf, 1945; see also the references to earlier literature by Schemm, 1944, who based his treatment of oedema on this principle). This may be due to loss of sodium and of extra cellular fluid. It is difficult to believe that Kunstmann was dehydrated during this experiment, as his weight remained constant. The rise in plasma chloride, with a negative chloride balance, indicates a marked loss of extra cellular water, which might have reduced the salivary flow.

Kourilsky maintains that the polydipsia in his cases was not a hysterical manifestation, though he does not deny the existence of ' potomanie.' This is bound to be the subject of controversy, though recent additions to our knowledge of the control of autonomic functions by specific cortical areas make this view seem less improbable than it would have done a few years ago. One of his cases was a young girl with a subarachnoid cyst which was stretching the pituitary stalk. While this was being aspirated she suddenly exclaimed that her thirst had gone. This resembles results sometimes produced by leucotomy.

Whether or not it is accepted that pathological thirst may be the result of lesions elsewhere than in the neuro-hypophysis or may arise from its partial destruction, the experiments of Kunstmann and others show that the excessive ingestion of water can produce a symptom complex identical with diabetes insipidus.

\section{Diagnostic Tests}

The tendency in Britain and America has been to divide these cases into two groups-diabetes insipidus and 'psychogenic polydipsia.' Carter and Robbins (r947) suggested that a rapid intravenous infusion of hypertonic saline, after preliminary hydration, will reduce the urine flow in the second group. This begs the question of the origin of the polydipsia, but they claim that the three cases so diagnosed were freed of their symptoms by psychotherapy.

Prolonged restriction of fluid is the usual diagnostic procedure. Sucking small pieces of ice or decicaine lozenges makes the ordeal more tolerable, but the patient will still complain of thirst. Severe cases become obviously dehydrated in a few hours, with little rise in the urinary specific gravity or fall in the urine flow. The gravity never exceeds roro and rarely reaches even this figure. Cases of polydipsia will be able to form a much more concentrated urine without any signs of dehydration, though the urine flow falls to much lower levels than in the first group and the test may therefore have to be prolonged for more than 24 hours. There remains a number of intermediate cases where there is probably sufficient hypophysial function left to form small amounts of $\mathrm{ADH}$ when dehydration is moderate; in these there may be a rise of urinary specific gravity above IOIO when some litres of fluid have been lost. The thirst and dryness of the mouth may be misleading indications of the degree of dehydration, as noted earlier. It is the urine flow and specific gravity considered against the fluid deficit that are of diagnostic importance.

Nicotine may also be valuable as a diagnostic aid. In the case previously referred to (Lewis, Ward and Bishop, I950) there was no response to hypertonic saline but smoking a cigarette produced a marked anti-diuresis. Further work on this test is now in progress in this unit.

\section{Lesions Associated with Diabetes Insipidus}

Cases occur where other signs of damage to the hypothalamus are present-emotional changes, adiposo-genital dystrophy, impotence, disturbances of sleep or of sweating and diabetes mellitus. The polyuria found in acromegaly may sometimes be due to pressure on the neurohypophysis by the enlargement in the anterior lobe.

These symptoms are the exception, however, and in the majority of cases diabetes insipidus is an isolated finding.

Fink (1928) analysed 107 post-mortem reports of cases with diabetes insipidus. In 63 per cent. there was a tumour at the base or in the posterior fossa, in 13 per cent. basal syphilitic meningitis or gumma, in 6 per cent. tuberculous meningitis or a tuberculoma and in 8 per cent. some other inflammatory process in this area, while in 10 per cent. trauma was responsible.

Jones (1944) reviewed the records of 42 cases treated in the University of Michigan Hospital between 1926 and 1943. Tumours involved the pituitary gland in II; one was a medulloblastoma. four were cystic adamantinomas and the others secondary deposits. There was a tumour involving the hypothalamus in two. Four suffered from Hand-Schüller-Christian disease, seven from chronic encephalitis, three from syphilis, three from the effects of head injury and three possibly from the results of vascular accidents. No cause could be found in eight, which were classed as 'idiopathic.' 
Kourilsky (1947) has emphasized the importance of upper respiratory tract infections as a cause, and cases following sphenoidal sinusitis have been reported (Yaskin, Lewey and Schwarz, 1942; Ball and Thackray, 1948).

Bollack, et al. (1937), found I 5 cases of diabetes insipidus among 129 of chiasmal arachnoiditis. Sinusitis or rhinitis were noted in $\mathrm{r}_{5}$ of the latter.

Colover (1948), reviewing the reports of 1 I 5 cases of sarcoidosis involving the central nervous system, states that polydipsia and polyuria were present in 20. Several showed other. symptoms due to lesions of the hypothalamus.

Porter and Miller (1948) have reviewed the cases occurring at the Head Injury Centre at Oxford. They reported 18 cases, 13 occurring in 5,000 admissions with non-fatal closed head injuries. The majority had severe injuries with more than seven days' post-traumatic amnesia. Symptoms were noticed between the ninth and thirty-first day after the injury. Of the 18 cases, only 12 had fractured skulls and these were not all basal. 'Eleven cases recovered within nine months.

Warkany and Mitchell (1939) have reviewed the condition in childhood.

Blotner (1942) and Williams (1946) have reported families with hereditary diabetes insipidus.

\section{Idiopathic Diabetes Insipidus}

The diagnosis of this condition calls for an extremely detailed case history and clinical examination, with X-rays of the skull and sinuses, lumbar puncture and perhaps encephalography to determine the underlying condition. In a small number, no evidence of one will be found and these are usually termed 'idiopathic.' A progressive lesion may declare itself even in some of these after time has elapsed. A primary growth was found in one of Jones' cases six years after the onset of polyuria, and in this unit a case has recently been seen to develop papilloedema after seven years. It has even been suggested (Bernstein, Moore and Fishback, 1938) that 'idiopathic' cases should be given deep X-ray therapy to the pituitary area on an empirical basis.

Isolated lesions destroying the supraoptic nuclei have been reported (Baker and Craft, I940) and it is possible that some cases have a selective degeneration of the supraoptico-hypophysial tracts.

The number of cases for which no cause at all can be found at any time must be comparatively small. A few of these may be found to be resistant to pitressin. The remainder probably includes those cases described by Kourilsky as ' pure polydipsias,' if it is indeed the case that they are not wholly psychological in origin.

\section{Treatment}

Apart from the treatment of the underlying condition, the polyuria can be controlled by replacement therapy.

Implantations of pellets and grafts of animal glands have been made, but have been unsuccessful.

Injections of posterior pituitary extracts will control the polyuria in the majority of cases, but this effect only lasts for a few hours. Occasionally they cause such unpleasant sensations, particularly abdominal cramps, that they have to be abandoned.

Intramuscular injection of pitressin tannate in oil, which delays the absorption, is usually much more successful. Many patients need only I or 2 cc. every two or three days and unpleasant sides effects are fewer (Court and Taylor, 1943).

Nasal insufflations of the dried gland are alse effective for short periods. Patients can take a? pinch of this snuff when they need to control the polyuria for a few hours and can judge the quantity without having to measure it accurately, or they may prefer to have it measured out in capsules. Some find it tos irritating to the mucous membrane.

Thyroidectomy has been recommended, particularly for those cases associated with postencephalitic Parkinsonism (Blotner and Cutler, I94I). Thiouracil was given to one 'idiopathic' case in the Middlesex Hospital by Dr. K. P. Ball, but without effect.

Restriction of salt and protein in the diet will reduce the polyuria and increase the effectiveness of pituitary extracts, but it must not be forgotten that salt deficiency may occur and be responsible for some of the symptoms in untreated cases.

\section{BIBLIOGRAPHY}

BAILEY, P., and BREMER, F. (1921), Arch. Int. Med., 28, 773. BAKER, A. B., and CRAFT, C. B. (1940), Endocrinology, 26, 801. BALL, K. P., and THACKRAY, A. C. (1948), Lancet, 1, 637.

BEASER, S. B. (1947), Amer. F. Med. Sci., 213, 44r. BELLOWS, R., and Van WAGENEN, W. P. (1938), f. Nerv.
Ment. Dis., 88, 417.

BERNSTEIN, M., MOORE, M. T., and FISHBACK, D. B. (1938), Arch. Ipt. Med., 62, 604.

BLOTNER, H. (1942), Amer. F. Med. Sci., 204, 26 r.
BLOTNER, H., and CUTLER, E. C. (1941), F. Amer. Med. Ass., I16, 2739 .

BOLLACK, J., DAVID, M., and PUECH, P. (1937), 'Les arachnoidites optochiasmatiques,' Paris.

BURN, J. H. (1931), Quart. F. Pharm., 4, 517.

BURN, J. H., TRUELOVE, L. H., and BURN, I. (1945), Brit. Med. F., I, 403.

CANNON, W. B. (1918), Proc. Roy. Soc. B., 90, 283.

CARTER, A. C., and ROBBINS, J. (I947), Ұ. Clin. Endoc., $7,752$. 
CHALMERS, T. M., LEWIS, A. A . G ., and PAWAN, G. L. (1950), '于.' Physiol.'.(in press).

COLOVER, J. (1948), Brain, 7I, 45 I.

COUTT, D., and TAYLOR, S. (1943), Lancet, I, 265.

CURTIS, G. M. (1921), Arch. Int. Med., 34, 801.

CUSHING, H. (1932), 'Papers relating to the Pituitary Body, Hypothalamus and Parasympathetic Nervous System, Charles C. Thomas, Springfield.

CUSHNY, A. R. (1926), 'The Secretion of the Urine,' Longman's Green \& Co., London.

DANDY, W. E. (1940), F. Amer. Med. Ass., 114, 312.

ELLMAN. P., and PARKES WEBER. F. (1949), Brit. Med. F., I, 304 .

FINK, E. B. (1928), Arch. Path., 6, 102.

FISHER, C., INGRAM, W. R., and RANSON, S. W. (1938), 'Diabetes Insipidus and the Neuro-Hormonal Control of Water Balance,' Edwards Bros., Ann. Arbor.

FU'TCHER, T. B. (1904), Tr. A. Amer. Physicians, 19, 247.

GILMAN, A. (1937), Amer. F. Physiol., 120, 323.

GREGERSEN, M. I. (1941), in Macleod's 'Physiology in Modern Medicine,' gth edition, Henry Kimpton, London.

GREGERSEN, M. I., and CANNON, W. B. (1932), Amer. $\mathcal{F}$. Physiol., 102, 336.

GROLLMAN, A., and WOODS, B. (1949), Endocrinology, 44, 409. voN HANN, F. (1918), Ztschr. f. Path., 21, 337.

HELLER, H., and URBAN, F. (1935), \%. Physiol., 85, 502.

HOLMES, J. H., and GREGERSEN, M. (1948), Amer. F. Med., 4, 503 .

JONES, G. M. (1944), Arch. Int. Med., 74, 8 I.

KELSALL, A. R. (1949), F. Physiol., 109, 150.

KENNAWAY, E. L., and MOTTRAM, J. C. (I9I9), Quart. f. Med., 12, 225.

KOURILSKY, R. (1947), Ann. Med., 48, 288.

KUNSTMANN, R. (1933), Arch. $\mathcal{F}$ Exp. Path., 170, 701.

LEWIS, A. A. G., WARD, C. S., and BISHOP, P. M. F. (1950), F. Endocrinol.' (in press).
MARX, H. (1926), Klin. Wchnschr., 5, 92

MONTGOMERY, M. (I931), Amer. F. Physiol., 96,' 22 I.

NOTHNAGEL, H. (1887), Virchow's Arch., 86, 435.

O'CONNOR, W. J. (1947), Biol. Rev., 22, 30.

PICKFORD, M. (1945), Physiol. Rev., 25, 573.

PICKFORD, M. (1947), 7. Physiol., 106, 264.

PICKFORD, M., and RITCHIE, A. E. (1945), f. Physiol., 104. I05.

PORTER, R. J., and MILLER, R. A. (1948), f. Neurol., Neurosurg. and Psychiat., Ir, 258.

RALLI, E., ROBSON, J. G., CLARK, D., and HOAGLAND, C. L. (1945), Ұ. Clin. Invest., 24, 316.

RIOCH, D., WISLOCKI, G. B., and O'LEARY, J. L. (1940), Res. Publ. Ass. Nerv. Ment. Dis., 20, 3.

ROUSSY, G., KOURILSKY, R., and MOSINGER, M. (1946), Rev. Neurol., 78, 313.

RYDIN, H., and VERNEY, E. B. (1938), Quart. F. exper. Physiol., 27, 343.

SCHEMM, F. R. (1944), Ann. Int. Med., 21, 937.

SMITH, HOMER W. (1947), Bull. N.Y. Acad. Med., 23, 177.

SWANN, H. G. (1939), Endocrinologi, 25, 288.

THEOBALD, G. W. (1934), f. Physiol., 81, 243.

THORN, G. W., and STEIN, K. E. (194I), f. Clin. Endoc., I, 680.

VEIL, R. '(1916), Deutch. Arch. f. Klin. Med., 119, 376.

VERNEY, E. B. (1946), Lancet, 2, 739 and 781.

WALKER, J. M. (1949), Quart. F. Med., 18, $5 \mathrm{I}$.

WARKANY, J., and MITCHELL, A. G. (1939), Amer. f. Dis. Child., 57, 603 .

WEIR, J. F., LARSON, E. E., and ROWNTREE, L. G. (1922), Arch. Int. Med., 29, 306.

WILLIAMS, R. H. (1946), f. Clin. Invest., 25, 937.

WINER, N. J. (1942), Arch. Int. Med., 70, 6 r.

WOLF, A. V. (1945), Amer. .. Physiol., 143, 567.

YASKIN, J. C., LEWEY, F. H., and SCHWARZ, G. (1942), Arch. Neurol. and Psychiat., 48, 19.

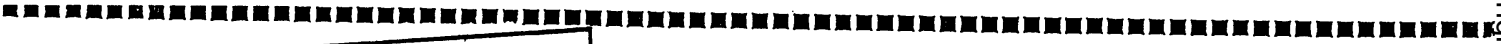

Why

'Ribena'

in

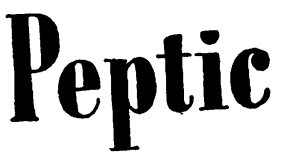

Ulleer?
Ribena is being increasingly prescribed in the treatment of Peptic Ulcer because controlled clinical tests have clearly indicated that natural vitamin $\mathrm{C}$, in the form of blackcurrant syrup, accelerated disappearance of symptoms and $\mathrm{X}$-ray evidence of ulcer. Detailed information on this work will be gladly sent to physicians.

Ribena is the pure undiluted juice of fresh ripe blackcurrants with sugar, in the form of a delicious syrup. Being. freed from all cellular structure of the fruit, it will not upset the most delicate stomach. It is particularly rich in natural vitamin C (not less than $20 \mathrm{mgm}$. per fluid ounce) and associated factors.

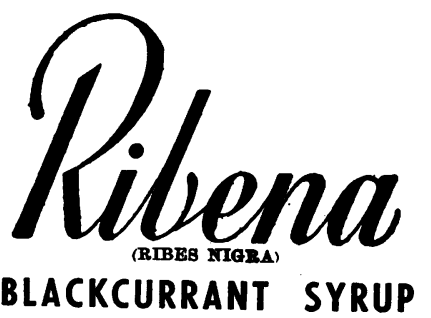

H.W. Carter \& Co. Let. (Dept. 5.K ), The Royal Forest Factory, Coleford, Glos Eire.-Inquiries should be addressed to Proprietaries (Eire) Ltd., 17/22, Parkgate Street, Dublin. 